\title{
MASCUlinity In ThOMAS MALORY's MoRTE DARTHUR
}

\author{
CHRISTOPH HOUSWITSCHKA
}

\begin{abstract}
Thomas Malory's Arthurian tale recurrently refers to the male body, and both the knights' physical and spiritual integrity are of crucial significance in maintaining masculinity. The male body represents power but is also threatened by physical violence and "fleshly lusts". Representing ideals of chivalry, masculinity in Morte Darthur oscillates between scenes of male power and experiences of anxiety. While Gareth represents moderation as a way of stabilizing the destructive forces of masculinity, Lancelot is determined to remain the strongest and most powerful knight, a position beyond control or condemnation. By avoiding the question whether Lancelot slept with the Queen, Malory transforms his gradual downfall into an epiphany of chivalric prowess. In a time of social disintegration the social acceptance of a knight's masculinity determines whether his personal individuality is to the benefit or to the destruction of the Arthurian fellowship.
\end{abstract}

Malory's Morte Darthur undoubtedly belongs among the most influential Arthurian stories in English Literature - kept alive by the best of British writers from Spenser to Tennyson and classics of the twentieth century such as T.H. White's The Once and Future King. Many more lovers of the Arthurian matter have almost invariably read and adopted the lengthy prose narrative of this - for quite some time - mysterious knight. ${ }^{1}$ Thomas Malory, who found himself in prison towards the end of the War of the Roses, summarized all the major Arthurian tales

\footnotetext{
${ }^{1}$ For the search after the true Thomas Malory, see, for example, Christina Hardyment, Malory: The Knight Who Became King Arthur's Chronicler, New York: Harper and Collins, 2005.
} 
of his time, both Old French and Middle English. Malory was looking for a new language that would drop the courtly tone of some of his sources, deliberately searching for words to match the world he lived in, a world of war and male codes of behavior, rewriting more or less any gendered narrative to a male perspective. Communication seems hardly to take place between the two sexes unless it maps out the intricacies of male power and anxieties signifying - generally speaking - anything but a genuine interest in women. ${ }^{2}$ With the exception of Guinevere, Isolde, or the Lady of Astolat, none of the female characters retains the complexities present in Malory's sources, none but Elaine of Astolat, who seems to be conceptionalized as an agent acting independently in the center of the subplot to which she belongs. ${ }^{3}$

Quite a few critics have suggested that Malory tampered so much with some of the subtle love stories in his sources because he had no interest in female characters such as Guinevere or Isolde. For Malory, one woman seems to have been as good as any other one. Unless he could represent differences in male characters by doing so, Malory's approach did not allow him to recognize individual differences among female characters, differences which he must have found in his sources. In the best case women are saved to bring honor to a knight; in the worst case women are sacrificed to save a man whose chivalric status or life is in jeopardy. The overruling question Malory tried to answer was whether the relationship between a given knight and his

\footnotetext{
${ }^{2}$ There are exceptions to this, such as the Lady of Astolat, who becomes the victim of Lancelot's unforgiving male principles. Elaine establishes a counter position that collapses Lancelot's fragile visions of perfectibility which are eventually jeopardized by his love to Queen Guinevere. I would argue, however, that Elaine of Astolat does not establish a female stance in the narrative, but rather in sacrificing herself stabilizes Lancelot's precarious masculinity for a little longer.

${ }^{3}$ Hodges refers to Armstrong who argues that the Pentecostal Oath's definition of chivalric manhood is dependent on vulnerable women: "Armstrong's analysis is important for revealing how chivalry constructs ideals of femininity even while it seems to dictate masculine behavior, and she is right that the two are interdependent" (Kenneth Hodges, Forging Chivalric Communities in Malory's Le Morte Darthur, New York: Palgrave Macmillan, 2005, 36). Marion Wynne-Davies claims that some women in Morte Darthur are less passive than this oath suggests (see Marion WynneDavies, Women and Arthurian Literature: Seizing the Sword, New York: St Martin's, 1996, 70-71). See also Dorsey Armstrong, Gender and the Chivalric Community in Malory's Morte d'Arthur, Gainesville: University Press of Florida, 2003; and Dorsey Armstrong, "Gender and the Chivalric Community: The Pentecostal Oath in Malory's 'Tale of King Arthur'", Bibliographic Bulletin of the International Arthurian Society, 51 (1999), 293-312.
} 
damsel or queen could inform the values of men in situations that might weaken their positions of power.

In her studies about Menacing Virgins, which also include chapters on male virginity in Morte Darthur, Kathleen Coyne Kelly voices a truism with regard to Malory when she confirms that "the female body has figured prominently as site, as meeting-place for ideological conflict. The male body, on the other hand, has been often and emphatically constructed literally, a thing in and of itself." ${ }^{4}$ Kelly argues that "when the male body is threatened ... a feminine and feminized body takes its place within the narrative frame". Substitution, then, is only one way of protecting the male body, where another one is "transformation of the masculine into the feminine for precisely the same reason - the feminized masculine body preserves the body chivalric from any real critique". ${ }^{5}$

This reading is based on R.W. Connell's assumption that gender relationships in patriarchal societies are defined by "body-reflective practices". ${ }^{6}$ These practices are inscribed into the body, which, being both agent and object, stabilizes hegemonial masculinity. In this understanding, gender "is a social practice that constantly refers to bodies and what bodies do, it is not social practice reduced to the body". ${ }^{7}$ Connell's concept emphasizes the connection between gender identity and social identity. Masculinity then assumes the hegemonic position by "the configuration of gender practices which embodies the currently accepted answer to the problem of the legitimacy of patriarchy which guarantees (or is taken to guarantee) the dominant position of men and the subordination of women". ${ }^{8}$

For Morte Darthur this means that, whenever Malory cannot avoid telling stories of gender relations, he almost exclusively reflects aspects of manhood referring to "a man in power, a man with power, and a man of power". ${ }^{9}$ The central concept containing these aspects in

\footnotetext{
${ }^{4}$ Kathleen Coyne Kelly, "Menaced Masculinity and Imperiled Virginity in Malory's Morte Darthur", in Menacing Virgins: Representing Virginity in the Middle Ages and the Renaissance, eds Kathleen Coyne Kelly and Leslie Marina, Newark: University of Delaware Press, 1999, 97.

${ }^{5}$ Ibid., 99.

${ }^{6}$ R.W. Connell, Masculinities, Berkeley: University of California Press, 1995, 27.

${ }^{7}$ Ibid., 71 .

${ }^{8}$ Ibid., 77.

9 Michael S. Kimmel, "Masculinity as Homophobia", in Privilege: A Reader, eds Michael S. Kimmel and Abby L. Ferber, Boulder, CO: Westview, 2003, 57.
} 
the Arthurian narrative is that of chivalric prowesse. Masculinity in Malory's Morte Darthur is represented by the precarious rivalries in male relationships that define war and peace, fellowship and civil strife, or more generally, power and anxiety. Following Todd W. Reeser, I would not like to define masculinity as a set of positive social values that are either observed or not. It is not an arbitrary dichotomy of ideal and reality as represented in fiction, but rather the instability of masculinity as a hegemonic effect in social and gender hierarchies - in Reeser's words: "Despite the various instabilities of the power theoretically engendered by moderation, masculinity should not be viewed as simply powerless either, for patriarchy and male power were in large terms still the norm in the period, particularly within the intellectual context of humanism." Reeser takes into account two aspects of masculinity, "its hegemonic, dominating aspects and its 'anxiety' or its 'neurosis". ${ }^{10}$ This tension is also found in Morte Darthur.

Being revised and printed in 1485 by William Caxton, Thomas Malory's Morte Darthur is informed by humanistic ideas in spite of the fact that it appears in many ways to be a strangely archaic text partially imitating old-fashioned styles of writing. The politics represented in this fashion, however, are nothing but archaic. They discuss Arthur's power in a highly versatile political environment in which magnates were as strong as the king himself or even stronger and the feudal order was based on a system of patronage. King Arthur's domination is not imposed by an overpowering warlord, but accepted to the mutual benefit of powerful men who want to avoid an all devouring war as Malory would have experienced himself during the Wars of the Roses. This contemporaneity of Malory's traditional Arthurian narratives has been described by Roberta Krueger for romances that "are remarkable for their authors' capacity to remake their shared stories anew in different contexts and to reposition their ethical systems as they respond to particular audiences, in distinct geographic locations and social contexts". ${ }^{11}$

Arthurian power is negotiated in the framework of hegemonic masculinity. Lacking legitimation in a military, dynastic, economic

\footnotetext{
${ }^{10}$ Todd W. Reeser, Moderating Masculinity in Early Modern Culture, Chapel Hill: University of North Carolina Press, 2006, 30.

${ }^{11}$ The Cambridge Companion to Medieval Romance, ed. Roberta L. Krueger, Cambridge: Cambridge University Press, 2000, vi.
} 
sense, not to speak of constitutional legitimation, late medieval power relations were personalized. For this reason Malory could identify each powerful knight with an aspect of order in the Arthurian world. Masculinity in Malory's world is constructed on the basis of a codified system of values and beliefs, laid out in the Pentecostal Oath that is either observed and defended as a legal framework of Arthurian Order or violated by individual knights performing acts of chivalric prowesse on their own terms. A knight's service for the common good, as represented in his protection of the weak, becomes the touchstone of this chivalric order's validity:

... the kyng stablysshed all the knyghtes and gaf them that were of londes not ryche, he gaf them londes, and charged hem neuer to doo outragyousyte nor mordre, and alweyes to flee treason. Also by no meane to be cruel, but to gyue mercy vnto hym that asketh mercy, vpon payn of forfeture of their worship and lordship of Kyng Arthur foreuermore, and alweyes to doo ladyes, damoysels, and gentylwymmen socour vpon payne of dethe. Also that no man take noo batails in a wrongful quarel for noo lawe, ne for no worldes goodes. Vnto this were all the knyghtes sworne of the Table Round, both old and young, and euery yere they sworne at the hyghe feest of Pentecost. ${ }^{12}$

The Pentecostal Oath is Malory's own invention. While the idealism of this oath is obvious, the reasons for its failure are assessed quite differently. While Dorsey Armstrong believes that both earlier episodes in the text and the Grail Quest in particular demonstrate "the full scope of the inadequacy of the Oath as a means of social order", ${ }^{13}$ one could also argue that it is not the oath but the chivalric code of prowesse which is doomed to collide with any legislative effort on the side of the King. ${ }^{14}$

${ }^{12}$ A New Edition of Thomas Malory's Le Morte Darthur. Based on the Pierpont Morgan Copy of William Caxton's Edition of 1485, eds James W. Spisak and William Matthews, Berkeley: University of California Press, 1983, 92, 11. 30-38. All quotations from Le Morte Darthur are from this edition.

${ }^{13}$ Dorsey Armstrong, "The (Non-)Christian Knight in Malory: A Contradiction in Terms?", Arthuriana, XVI/2 (Summer 2006), 30.

${ }^{14}$ For love and power in Malory, see Christoph Houswitschka, Politik und Liebe in der Literatur des englischen Spätmittelalters am Beispiel von Thomas Malorys Morte Darthur, Frankfurt am Main: Peter Lang, 1991, and for the flaws of idealistic knights, Christoph Houswitschka, "From Vision to Vainglory: Malory as a Critic of Idealism in the Morte Darthur", in Of Remembraunce the Keye: Medieval Literature and its Impact through the Ages, ed. Uwe Böker, Frankfurt am Main: Peter Lang, 2004. 
Through the regulations of the Pentecostal Oath, Arthur keeps his knights in check, as Karen Cherewatuk explains: "The annual Pentecostal celebration, at which the knights renew this oath, reinforces the hierarchical bonds of love, loyalty, and fear that both Aristotle and Malory advocate, for the king is head of all knighthood." 15

The Pentecostal Oath also talks about male obligations to women of high rank. ${ }^{16}$ Robeson points out that the behavioral restraints for men embodied in the Pentecostal Oath pave the way to achieve "worship by honouring that [that is, worship] of women; certainly women maintain their worship more easily when not threatened by rape or abduction". While any knight "who violates a woman's worship by raping or abducting her automatically sacrifices his own" ${ }^{17}$ women must follow the rules that define fifteenth-century sexual mores. ${ }^{18}$

The oath is a well established form of social contract binding together individuals in a consensual group based on shared interests, values and norms. Otto Gerhard Oexle points out that such oaths bind together persons who do not find their own people in pre-existing relationships such as kinship, but choose to create the group they belong to. Oexle asks what this distinction means in terms of our understanding of individuality in medieval society. This form of sworn federation of co-operating groups had some common roots in feudalism (lord and vassal), but is more typical of civic communities. ${ }^{19}$

\footnotetext{
${ }^{15}$ Karen Cherewatuk, "Sir Thomas Malory's 'Grete Booke",, in The Social and Literary Context of Malory's Morte Darthur, Arthurian Studies 42, eds D. Thomas Hanks Jr. and Jessica Gentry Brogdon, Cambridge: D.S. Brewer, 2000, 54.

${ }^{16}$ Women also show "loyalty to their obligations and (perhaps surprisingly) to the ideals of the Round Table set out in the Pentecost Oath. It is often said that ladies are obliged to remain virgins before marriage and faithful to their husbands afterwards, that that is the equivalent of a knight's obligation to show courage in battle, and that knights have no more obligation to chastity than ladies to courage in combat" (ReViewing Le Morte Darthur: Texts and Contexts, Characters and Themes, eds K.S. Whetter and Raluca L. Radulescu, Woodbridge: Brewer, 2005, 5).

${ }^{17}$ Lisa Robeson, "Women's Worship: Female Versions of Chivalric Honour", in ibid., 110 .

${ }^{18}$ The Winchester Manuscript is clearer in this respect explicitly condemning rape as a crime: "and allwayes to do ladyes, damesels, and jantilwomen and wydowes socour: strengthe hem in hir ryghtes, and never to enforce them, uppon payne of dethe" (The Works of Sir Thomas Malory, ed. Eugène Vinaver, 3 vols, 2nd edn, Oxford: Clarendon Press, 1971, 120.

${ }^{19}$ Otto Gerhard Oexle, "Konsens-Vertrag-Individuum: Über Formen des Vertragshandelns im Mittelalter", in Das Individuum und die Seinen: Individualität in der okzidentalen und in der russischen Kultur in Mittelalter und früher Neuzeit, eds Jurij
} 
Malory places the Pentecostal Oath in his work in the tradition of similar oaths in orders of knighthood. ${ }^{20}$ These chivalric communities help administer and police King Arthur's realm and offer "valuable perspectives on the way in which late-fifteenth-century communities were imagined". Kenneth Hodges convincingly shows that these communities also provided "the common core of proto-nationalist sentiment" as the number of readers of chivalric literature grew. ${ }^{21}$ Oexle explains that this kind of oath could be found in both a civic coniuratio and in aristocratic groups of persons who are bound together in a community of different and unequal rights and duties. For lords and vassals, the oath defines a whole new way of acting among one another, what Max Weber calls the making of a "sworn brotherhood" (Verbrüderung). ${ }^{22}$

While the conflicts in Malory's Morte Darthur, especially those between the main representatives of the two most powerful families in Arthur's kingdom, can be approached from the perspective of competing communities within the Round Table, the battles among the descendants of Lot and Pellinore are carried out between individuals who are guided by their ideas of chivalric prowesse. ${ }^{23}$ Prowesse is the

L. Bessmertnyj and Otto Gerhard Oexle, Göttingen: Vandenhoeck und Ruprecht, 2001, 15-16.

${ }^{20}$ In Boulton's understanding, these orders offered "a form of reciprocal relationship" (D'Arcy Jonathan Dacre Boulton, The Knights of the Crown: The Monarchial Orders of Knighthood in Later Medieval Europe 1325-1520, Woodbridge: Boydell and Brewer, 1987, 15). The most common term was "companion (socius, compaignon, compagno)" (ibid., 458) who would have "to take a special oath of love and loyalty to their fellow companions, very similar to that undertaken by brothers-of-arms" defining "mutual obligations" (ibid., 467).

${ }^{21}$ Hodges, Forging Chivalric Communities in Malory's Le Morte Darthur, 7. In his popular handbook, The Book of the Order of Chivalry, written probably between 1279 and 1283, Ramon Llull "specifically urges the body of right-thinking knights to act as a policing agency themselves, admonishing them even to be willing to kill those knights who dishonour the order of chivalry, as in the case (which so obviously troubles him) of knights who are thieves and robbers, wicked and traitorous" (Richard W. Kaeuper, Chivalry and Violence in Medieval Europe, Oxford: Oxford University Press, 1999, 278).

${ }^{22}$ Oexle, "Konsens-Vertrag-Individuum", 16.

${ }^{23}$ See Hodges' analysis of the conflicting loyalties towards the family and the Pentecostal Oath: "Blood-feud ... persists even as other, newer styles of chivalry come into being. It is during Balin's adventures that Pellinore kills Lot in battle, and through the rest of Le Morte Darthur Lot's sons, Gawain and his brothers, pursue their feud with Pellinore's sons, Lameroke in particular. And Mordred, the living reminder of the dangers of not recognizing family, lurks to bring down Arthur in the 
chivalric aspect of masculinity representing a given knight's individuality. Masculinity then is gendered individuality, embedded in a specific social, cultural and historical context and at the same time expressing a person's individual development. ${ }^{24}$ Max Fuchs describes individuality in the context of "personality", a term that describes a natural being with reason and responsibility within a social system of norms. ${ }^{25}$ Fuchs explains that the concept of individuality as a person's property is not a Renaissance invention. In the Middle Ages a person is an individual who is endowed with reason and a moral sense that gives to him the power of choice. ${ }^{26}$ This claim places Fuchs in line with Jan A. Aertsen and the majority of medievalists. ${ }^{27}$

Fuchs shares this position with historians such as Oexle, who is also critical of the fact that our understanding of the relationship between individuals and groups is still very much determined by two grand narratives of the nineteenth century. In his classic Die Kultur der Renaissance in Italien: Ein Versuch (1860), Jacob Burckhardt suggests that the Renaissance marks the beginning of modernity because the individual has liberated him - or herself from the bonds of faith and social groups such as family, social status et cetera. This narrative of social progress was counterpoised with Ferdinand Tönnies' narrative of decline in Gemeinschaft und Gesellschaft (1887), who defined society (Gesellschaft) as mechanistic and consisting merely of rational contractual relations among individuals as opposed to the organic bonds that exist among people gathered in a community (Gemeinschaft). In Tönnies' reading the history of individuality was one of emancipation, replacing a feeling of belonging and protection with the isolation and fragmentation the individual would encounter in anonymous masses.

Both these narratives share the belief that there was no concept of individuality in the Middle Ages and that there were no contractual

end. These two enduring elements of the book are engendered at precisely the time chivalry has added the honoring of reciprocal obligations to its celebration of prowess, resulting in an ideal of blood feud that never goes away" (Forging Chivalric Communities in Malory's Le Morte Darthur, 48).

${ }^{24}$ See Max Fuchs, Persönlichkeit und Subjektivität: Historische und systematische Studien zu ihrer Genese, Opladen: Leske und Budrich, 2001, 9.

${ }^{25}$ Ibid., 27.

${ }^{26}$ See ibid., 129.

${ }^{27}$ Individuum und Individualität im Mittelalter, eds Jan A. Aertsen and Andreas Speer, Berlin: de Gruyter, 1996, xvi. 
relations. Oexle points out that Burckhardt's and Tönnies' narratives still have a tremendous impact on our debates about the individual or individuality and about the self or subjectivity. ${ }^{28}$ Although medievalists have long since established the presence of a concept of individuality in medieval thinking, many scholars continue to deny the concept's applicability to the period.

Malory lived in a time when many ideas of the Italian Renaissance had already found their way to England via Burgundy and such translators and publishers as William Caxton. Therefore, individuality, whether in the medieval or renaissance sense, plays a major role in defining the contractual relations in the Arthurian community of the Round Table. Malory's Pentecostal Oath tries to balance out the contractual relations against the interests of individual knights who are more likely to strengthen their masculinity or, in chivalric terms, their prowesse.

The narratives about King Arthur's knights and the prowesse they earn are based on a concept of masculinity which illustrates the delicate balances that keep the power relations in the world of Camelot gradually moving from rise to climax and up to its fall. Malory's concept of masculinity keeps both patriarchal hegemony and its anxieties in a precarious balance. Malory's stories of love and marriage, of bonds of friendship and family, keeping peace and waging war, and showing loyalty and committing treason, illustrate these conflicting forces of masculinity. Malory's language of masculinity represents those aspects of power that keep the Arthurian order together.

The education he received as a member of the lower gentry formed the basis of Malory's rhetoric of masculinity. Had he been the Malory of Newbold Revel, he would have been educated as a lay aristocrat of later medieval England:

The grammar education of the son of a gentle or aristocratic family usually took place in the home and lasted approximately six years, from the age of six or seven until fourteen. The instruction was the re-

\footnotetext{
${ }^{28}$ See Oexle, "Konsens-Vertrag-Individuum”, 22-23. The endurance of Burckhardt's assessment of individuality in the Middle Ages is criticized throughout medieval studies (see Henryk Anzulwicz, "Grundlagen von Individuum und Individualität in der Anthropologie des Albertus Magnus", in Individuum und Individualität im Mittelalter, 125; and Klaus Jacobi, "Einzelnes-Individuum-Person: Gilbert von Poitiers' Philosophie des Individuellen", in ibid., 3) and has become a common place (cf. Fuchs, Persönlichkeit und Subjektivität, 128).
} 
sponsibility of professional schoolmasters, most with university education in grammar, others possessing at least the highest level of their most advanced students .... Rhetoric was an essential and primary element in the artes liberates and, as such, was at the heart of the educational curriculum. ${ }^{29}$

Malory uses this rhetoric "in such a way as to bring about certain preferred interpretations". "In doing so", we learn from Hanks, "he interprets chivalry as giving meaning, value, and even triumph to the individual male life". ${ }^{30}$ The rhetoric of masculinity is associated with recurrent references to the male body in metaphors and phrases. Both the knights' physical and spiritual integrity are of crucial significance in maintaining masculinity. The male body, representative of power, encounters threats to its integrity.

These threats, coming from outside the body, take the form of the weapons of adversaries as well as the temptations of the flesh, what Malory calls "lycours lustes". ${ }^{31}$ In his famous passage likening love to May, "he defines virtuous love as being based on restraint and balanced priorities". ${ }^{32}$ Such "hote lustes", 33 as Dame Lyones' feelings for Sir Gareth are called, threaten the integrity of the male body from outside. The body is described as a container of certain qualities capable of endangering a person from within, just as he might be destroyed from without. Lancelot acknowledges this when he talks about traitorous knights around King Mark and Tristram: "hard hit is to take oute of the fleshe that is bred in the bone" ${ }^{34}$ he says, trying to explain why some knights cannot live up to the high standards of Arthurian knighthood.

Power and anxiety cannot be separated since power cannot be achieved without danger. When Pellinore, who takes on the quest of pursuing the "Questing Beast", meets Arthur and asks him for a horse, he explains to the King: "I haue folowed this quest this xii moneth, and other I shal encheue hym, or blede of the best blood of my

${ }^{29}$ Ann Dobyns and Ann Laskaya, "Introduction: Rhetorical Approaches to Malory's Morte Darthur", Rhetorical Approaches to Malory's Le Morte Darthur, eds Ann Dobyns and Ann Laskaya, Arthuriana, XIII/3 (Fall 2003), 4.

${ }^{30}$ D. Thomas Hanks Jr, "The Rhetoric of the Folk Fairy Tale in Sir Thomas Malory's 'Tale of Sir Gareth'”, Arthuriana, XIII/3 (Fall 2003), 58.

${ }^{31}$ Spisak and Matthews, New Edition of Malory's Le Morte Darthur, 573, 1. 32.

${ }^{32}$ Hodges, Forging Chivalric Communities in Malory's Le Morte Darthur, 130.

${ }^{33}$ Spisak and Matthews, New Edition of Malory's Le Morte Darthur, 181, 1. 14.

${ }^{34}$ Ibid., 287, 1. 17. 
body." 35 This quotation shows that the tension between power and anxiety is not exclusive. The knight does not fear his vulnerability but rather sees it as a consequence of any loss of power. Therefore Merlin explains elsewhere that "it is Gods wyll, youre body to be punysshed for your fowle dedes". ${ }^{36}$ A knight's body represents his chivalric prowesse. It is the identification of the two, however, that Malory emphasizes so strongly in language that creates masculinity as an ideological concept. Whatever truth a knight wants to prove, he must be willing to "preue it on his body" ${ }^{37}$ This and similar expression appear frequently. "He is a passyng good man of his body", ${ }^{38}$ we learn, or "for he was a good man named of his body". 39

Consequently, violence and combat, in so far as they threaten the male body to be destroyed or disfigured, are the only proof of a knight's valiance and nobility. The body is a vessel protecting the specific virtues that define chivalric prowesse. Some wounds may be healed, but others damage the body so severely that the knight perishes both physically and as a male capable of protecting his masculinity. Expressions such as "the hauberk perysshed, and so percyd thurgh his body and the hors croppe" 40 establish an image of the total disfiguration and destruction of the male body. This signifies the annihilation of a knight's masculinity, not only the destruction of his body.

This difference is explained in an early provocation young King Arthur faces when he is challenged by the messenger of King Ryons who had "a mantle with kynges berdes". ${ }^{41}$ When the messenger asks for Arthur's beard, the King is outraged. The beard symbolizes Arthur's and the other Kings' masculinity. Although the loss of the beard would not threaten a man's life, the beard here represents the integrity of the male body, which is to be defended at all costs. Therefore, King Arthur replies to King Ryons' messenger:

... also thow mayst see my berd is ful yong yet to make a purfyl of hit. But telle thow kynge this: I owe hym none homage, ne none of myn elders, but or it be longe to he shall do me homage on bothe his kneys,

\footnotetext{
${ }^{35}$ Ibid., 54, 11. 31-32.

${ }^{36}$ Ibid., 55, 1. 24.

${ }^{37}$ Ibid., 56, 1. 6.

${ }^{38}$ Ibid., 61, 1. 2.

${ }^{39}$ Ibid., 63, 11. 23-24.

${ }^{40}$ Ibid., 66, 11. 37-38.

${ }^{41}$ Ibid., 60, 1. 29.
} 
or els he shall lese his hede, by the feith of my body, for this is the most shamefullest message that euer I herd speke of. ${ }^{42}$

The beard stands here pars pro toto for the entire body: honor, not the body itself, is forfeited with the loss of the beard.

This explains why Bagdemagus refuses to "retorne vnto the courte ageyne tyll he had wonne a knyghtes body of the Round Table, body for body". ${ }^{43}$ Only then will "men speke of me grete worship and that I be worthy to be a knyghte of the Rond Table", ${ }^{44}$ Bagdemagus explains. Expressions such as "to fyghte for the lyuelode, body for body" ${ }^{45}$ show that a knight's honor is represented by the integrity of his body. From our modern perspective the exchange value of bodies might be compared to that of money in a capitalist society. The difference, however, is shown with King Ryons. To accumulate a large number of beards only for the sake of completing "a mantle with kings' beards" does not honor the construction of masculinity as an essentialist category any longer. The beard only symbolizes the exchange value of the body. Therefore the formula that one can draw from this and that defines masculinity is - somewhat simplified "body for body", not "beard for beard".

One of the most moving of Malory's episodes exploring the significance of the male body is that of Balyn. Balyn kills a knight whose mistress cannot bear her loss:

O Balyn, two bodyes thou hast slayne in one herte, and two hertes in one body, and two soules thow hast lost. And therwith she toke the swerd from her loue that lay ded and fylle to the ground in a swowne, and whan she aroos she made grete dole out of mesure, the whiche sorowe greued Balyn passyngly sore. And he wente vnto her for to haue taken the swerd oute of her hand, but she helde it so fast, he myghte not take it oute of her hand onles he shold haue hurte her, and sodenly she sette the pomell to the ground, and rofe herself thorow the body. When Balyn aspyed her dedes he was passynge heuy in his herte and ashamed that so fair a damoysell had destroyed herself for the loue of his deth. Allas, said Balyn, me repenteth sore the deth of

\footnotetext{
${ }^{42}$ Ibid., 60, 11. 33-37.

${ }^{43}$ Ibid., 97, 11. 21-22.

${ }^{44}$ Ibid., 97, 11. 24-25.

${ }^{45}$ Ibid., 99, 1. 1.
} 
this knyght for the loue of this damoysel, for ther was moche true loue betwixe them bothe, and for sorowe myght not lenger behold hym. ${ }^{46}$

Chivalric prowesse is demonstrated on the basis of a specific understanding of masculinity and the integrity of the male body. In this episode, however, we are introduced to more complex aspects of masculinity that cannot be constructed on the level of rhetoric any longer. In order to present the more intricate dangers and dilemmas any knight must face using violence as a cultural practice, more complex symbolical structures of narrative art are required. These more subtle social conflicts go beyond combat encounters. Balyn regrets the killing of the knight because both, the knight and his mistress, were united in a relationship of true love. This true love is the most honored bond between men in Camelot.

By killing this knight Balyn damages the very foundation of the political order in King Arthur's realm. His repentance proves him to be a knight who acknowledges the fact that the other knight's true love was a valid one in spite of the fact that he became the adversary of his own prowesse. Balyn's reckoning shows that any ideology based on the defense of individual masculinity must conflict with its own assumptions the moment obligations towards the community conflict with personal goals. Being defined by masculinity, the knight's individuality precedes any chivalric code of behavior or sense of community. While the knight's sense of his own individuality takes precedence over his chivalric duties, the fellowship of the Round Table is required to stabilize the difficult concept of community.

The Pentecostal Oath tries to civilize masculinity in order to avoid collision with the interests of community. If it were for a mere honorand-shame culture as was suggested in the Seventies and Eighties, ${ }^{47}$ this masculinity would have a strong element of social control to it. However, Malory's Morte Darthur introduces us into a world of strong individual rights where the honor of a knight's prowesse ought to earn a lady's love. The obvious problem that remains is whether this is done in a way that is not destructive to the community. The ideal is voiced in various places in Morte Darthur. When, for exam-

\footnotetext{
${ }^{46}$ Ibid., 67, 11. 3-13.

${ }^{47}$ See Mark H. Lambert, Malory: Style and Vision in Le Morte Darthur, New Haven, CT: Yale University Press, 1975, 178; Lisa Robeson,"Noble Knights and Mischievous War': The Rhetoric of War in Malory's Le Morte Darthur", Arthuriana, XIII/3 (Fall 2003), 29 .
} 
ple, Sir Kay smote a king "so hard on the helme that the stroke clafe the helme and the hede to the erthe", ${ }^{48}$ King Arthur is delighted:

That was wel stryken ... and worshipfully hast thow hold thy promesse; therefor I shal honoure the whyle that I lyue .... Quene Gweneuer praysed Syr Kay for his dedes and sayd, what lady that ye loue, and she loue yow not ageyne she were gretely to blame. And amonge ladyes, said the quene, I shalle bere youre noble fame, for ye spak a grete word and fulfylled it worshipfully. And therwith the quene departed. ${ }^{49}$

Honor is established by the King's praise and recognition; however, its social consequences are expressed differently. No lady with whom Sir Kay would fall in love could possibly reject a knight of such honor without losing hers. Guinevere's statement is important, since, by the same reasoning, she is not permitted to reject Lancelot's love. This, however, indicates that masculinity empowers the male individual to a degree that his chivalric prowesse may collide with his social loyalties at any time.

In Malory's interpretation of the tradition of Lancelot's character, masculinity seems to be a concept that brings a knight's social responsibility into jeopardy. The more Lancelot's masculinity - or, rather, one should rather say, his body - is threatened in combat or by seduction, the more difficult it gets for the knights of the Round Table to tolerate his exceptional prowesse. The uniqueness of his prowesse is the mark of an individual who cannot be controlled: masculinity cannot be a concept respecting social restrictions unless a knight sacrifices himself or is defeated. Quite inevitably, Lancelot cannot offer to yield to either of these solutions. For the same reason it is inevitable that he would love the Queen, and indeed, possessing at least as much prowesse as King Arthur, he deserves her love. Therefore Merlin warns Arthur "that Gweneuer was not holsome for hym to take to wyf, for he warned hym that Launcelot shold loue her, and she hym ageyne". ${ }^{50}$

At the beginning of Morte Darthur, Lancelot's relationship to King Arthur and his specific role in Camelot is determined by his explicit intention to serve Arthur without claiming land or power for himself.

\footnotetext{
${ }^{48}$ Spisak and Matthews, New Edition of Malory's Le Morte Darthur, 95, 11. 35-36.

${ }^{49}$ Ibid., 95, 11. 36-42.

${ }^{50}$ Ibid., 80, 11. 19-20.
} 
This is markedly different from the members of Arthur's kinship, particularly Gawain who claims power in Arthur's realm, his brother Gareth who becomes a feudal lord in the provinces, or those very few knights who achieve spiritual knighthood and serve God such as Galahad and Perceval.

In spite of their differences, the leading knights of Camelot share the same prowesse. Masculinity, however, is defined differently. While all of them must prove to be excellent soldiers, the point of departure is represented in their sexual conduct. Galahad's masculinity is defined by male virginity; Gawain's masculinity, on the other hand, is traditionally defined by the opposite. That Lancelot neither remains a virgin nor (later on) endures chastity in his relationship to Guinevere illustrates specific aspects of his masculinity. Male virginity or chastity signifies the absence of any claim for political power. The more Lancelot engages in sexual adventures, the less likely it is that his power will be tolerated by Gawain and other suspicious Arthurian knights. This is a singular threat to Arthur's power. The moment Lancelot is tricked into a sexual encounter and loses his virginity his downfall begins, along with that of Camelot as a whole. Eventually, he will be suspected of having slept with the Queen. In other words, Lancelot's adversaries regard his prowesse as a threat to the kingdom, because the strongest knight's masculinity collides with his contractual responsibilities.

Why is sexual love such a destructive power in chivalric society? Sexual love in Thomas Malory's Morte Darthur carries that meaning for religious reasons. Even in the Queste del Saint Gral, Malory takes the destructive power of sexual love from his sources without conveying any major sense of chivalric achievement which can be found there. ${ }^{51}$ Following the Governance of England by Sir John Fortescue,

${ }^{51}$ See Ferguson: "The idea of the Christian knight could lead to the life of chastity and selfdenial exemplified in Galahad and aspired to somewhat overoptimistically by Launcelot. And among the earnest apologists for the chivalric ideal in the fifteenth century there is especially discernible a suspicion of wine and women and of selfindulgence in any form. But this is the asceticism of the dedicated soldier" (Arthur B. Ferguson, The Indian Summer of English Chivalry: Studies in the Decline and Transformation of Chivalric Idealism, Durham, NC: Duke University Press, 1960, 97). 
however, one could argue that a lack of chastity leads to pride,${ }^{52}$ this being one of the reasons why Fortescue deplores the decay of the aristocracy. ${ }^{53}$ Focusing on masculinity one comes to the conclusion that sexual love represents an aspect of masculinity that causes an individual knight's prowesse to turn against the community as a whole. Following the norms of his age, Fortescue identifies pride as the prime deadly sin.

In modern terms one could compare this with egotistic individualism. I do not want to do away with the significant historical differences and, moreover, would find it quite difficult to apply the term "individualism" to a late medieval society. A knight's individuality is represented by his chivalric prowesse, which is not a bad thing as such. However, this prowesse is rooted in a concept of masculinity that is almost exclusively represented by the male body and therefore it is very likely to defy all social restrictions that limit a knight's power or provoke anxieties of loss. It is the extreme gendering of this masculinity in a knight's individual personality that leaves no space to define the social other in the narrative.

For this reason, the significance of Lancelot's love affair with Elaine has been explored in gender studies. Lancelot's refusal of Elaine should not be seen as being "motivated by a fear that she might claim the feminine within him, which his life dedicated to male bonding denies", as Donavin suggested. ${ }^{54}$ This would exclusively identify love with the feminine as opposed to "his masculine strength" (in Donavin's definition) ${ }^{55}$ Rather, sexual desire shows the uncontrolled individuality of the masculine destroying the ideals of chivalric prowesse. Masculinity should not be reduced to military strength nor should love be exclusively identified with the feminine. In Malory's text, love or sexual desire is an aspect of masculinity characterizing the social acceptance of chivalric prowesse. Therefore, Donavin's evasive explanation that even "Lancelot's affair with Guinevere, an unattainable woman who often requires him to demonstrate his masculine strength, distances him from knowledge of and relationship to

\footnotetext{
${ }^{52}$ See John Fortescue, The Governance of England: Otherwise Called the Difference between an Absolute and a Limited Monarchy (1885), ed. Charles Plummer, Oxford: Oxford University Press, 1926, 79-81.

${ }^{53}$ See ibid., 104.

${ }^{54}$ Georgiana Donavin, "Elaine's Epistolarity: The Fair Maid of Ascolat's Letter in Malory's Morte Darthur", Arthuriana, XIII/3 (Fall 2003), 71.

${ }^{55}$ Ibid., 78.
} 
the feminine" ${ }^{, 56}$ fails to contextualize Malory's use of masculinity in the work as a whole. In the context of Malory's Morte Darthur, femininity is absent as a signifying concept describing the social other. Malory does not, as Donavin suggested, advance "Elaine's feminist voice" to any extent and does not even try to "dramatize the difficulty of establishing a feminine subject position in the male-dominated Arthurian world". ${ }^{57}$

The male subject positions in Malory's Morte Darthur allow for hardly any feminine subject position or social commitment. The fellowship of the Round Table functions on the basis of a contractual community that acknowledges the right of each knight to strengthen his masculinity so long as in doing so, he does not intentionally damage this community. The acceptance into the fellowship of the Round Table implies the solemn promise to acknowledge the other knight's chivalric prowesse as much as it is possible to do so. Malory confronts his readers with a vision of masculine individuality in a group of equal males who celebrate their unique achievements.

How is this contractual community kept together under such premises? The answer is by mutual consent, as represented by love. In the context of sexual love, these contractual relations based on mutual consent occur in two cases, in Gareth's marriage and in Lancelot's agreement with Guinevere not to consummate their love. In both cases sexual love is an exclusive aspect of these contractual relationships. In the case of Gareth, sexual love is not mentioned after marriage, and in Lancelot's case it ought never to have been mentioned. It is the absence of any communication about sexual love that shows that the contractual community of the Round Table is still unharmed. As soon as sexual love is mentioned, it means that social responsibilities are defeated by a knight's individuality. That sexual love goes unmentioned does not necessarily mean it is absent - an absurd assumption in Malory's understanding. It is rather the case that the knights do not worry about it, as it could violate their own interests, that is, those of the contractual community. Such a contractual community or "fellowship" is a compact of equals based on a mutual concession of individual freedom and requiring an oath of commitment. In the Pentecostal Oath Arthurian knights remind themselves each year of their holy duties.

${ }^{56}$ Ibid., 71.
${ }^{57}$ Ibid., 77. 
The wedding of Arthur and Guinevere marks the first occasion of the ratification of this oath. The contractual obligations laid out in the oath define the boundaries of individual masculinity. Significantly, this is done in negative terms, defining what is absolutely forbidden rather than what is allowed. There is no female subject position in Thomas Malory's narrative because the concept of masculinity among Arthurian knights does not acknowledge any restrictions of chivalric prowesse unless the integrity of the male body is in danger. This is illustrated by an episode which is told in the context of Gareth's search for a bride. When Gareth is invited into Persante's castle, the host's daughter is sent to Gareth's bed chamber:

When Beaumayns was abede, Syr Persaunt had a lady, a faire doughter of xviiii yere of age. And there he called her vnto hym and charged her and commaunded her vpon his blessynge to go vnto the knyghtes bedde, and lye doun by his syde, and make hym no straunge chere, but good chere, and take hym in thyne armes and kysse hym; and loke that this be done, I charge you, as ye wil haue my loue and my good wil. So Syr Persants doughter dyd as her fader bad her. ${ }^{58}$

Gareth, however, rejects the damsel when he learns that she is a virgin in order not to treat his host dishonorably:

Be ye a mayde or a wyf? said he. Sir, she said, I am a clene maiden. God defende, sayd he, that I shold defoyle you to doo Syre Persaunt suche a shame. Therfore, fayre damoysel, aryse oute of this bedde, or els I wille .... I were a shameful knyghte and I wold do your fader ony disworship. And so he kyst her. ${ }^{59}$

When she tells her father about Gareth's words, Sir Persant is satisfied: "whatsomeuer he be, he is comen of a noble blood." one's daughter to a visiting knight is a stock motive in medieval literature. Malory uses it neither to tell us about the role of women in his times nor about the significance of female virginity, but rather about

\footnotetext{
${ }^{58}$ Spisak and Matthews, New Edition of Malory's Le Morte Darthur, 170, 11. 26-31.

${ }^{59}$ Ibid., 11. 34-39.

${ }^{60}$ Ibid., 1. 41.
} 
the "godelye comynycacyon bytwene Syr Persaunt and Beaumayns", ${ }^{61}$ as we learn from the title of this episode.

In Lancelot's case masculinity reaches a maximum of individual fulfillment that transcends all social boundaries. After his death Ector describes Lancelot in the following words:

... thou were hede of al Chrysten knyghtes ... thou were neuer matched of erthely knyghtes hande. And thou were the curtest knyght that euer bare shelde; and thou were the truest frende to thy louar that euer bestrade hors; and thou were the trweste louer of a synful man that euer loued woman; and thou were the kyndest man that euer strake wyth swerde; and thou were the godelyest persone that euer cam emonge prees of knyghtes; and thou was the mekest man and the ientyllest that euer ete in halle emonge ladyes; and thou were the sternest knyght to thy mortal foo that euer put spere in the reeste. ${ }^{62}$

All these various aspects of Lancelot's superior knighthood reflect his unmatched masculinity that is honored outside any other normative framework of the defining social order. Liberated from the forces of social loyalties, Lancelot embodies an ideal of masculinity unmatched by any other knight and venerated independently of the social consequences of his chivalric prowesse. Lancelot's masculinity is that of a knight created by Thomas Malory in times of social disintegration. Masculinity becomes the ultimate expression of individual personality. Malory's concept of masculinity shares only a few features with that of the literature of the Italian Renaissance: it is masculinity hardly controlled by moderation or the anxieties of jealousy. While masculinity in the Italian Renaissance is modified by the acknowledgement of the other, for instance, empowering female characters by attributing knowledge to them which then threatens masculinity, ${ }^{63}$ Malory speaks mainly of the anxieties of being wounded in an act of violence. Malory's knights belong to a time of social disintegration in which the social acceptance of a knight's masculinity determines whether his per-

${ }^{61}$ Title of Chapter 13 of "The Tale of Sir Gareth of Orkeny That was Called Bewmaynes", which can be found in the contents (ibid., 12).

${ }^{62}$ Ibid., 599, 11. 5-13.

${ }^{63}$ See, for example, Breitenberg's interpretation of Othello: Mark Breitenberg, Anxious Masculinity in Early Modern England, Cambridge: Cambridge University Press, 1996. 
sonal individuality is to the benefit or to the destruction of the Arthurian fellowship. 